HoST - Journal of History of Science and Technology

Vol. 14, no. 2, December 2020, pp. 13-49

$10.2478 /$ host-2020-0013

\title{
The Struggle for Objectivity: Gramsci's Historical-Political Vistas on Science against the Background of Lenin's Epistemology
}

\author{
Pietro Daniel Omodeo \\ Ca’ Foscari University of Venice \\ pietrodaniel.omodeo@unive.it
}

\begin{abstract}
This contribution interprets the intertwined issues of science, epistemology, society, and politics in Gramsci's Prison Notebooks as a culturalist approach to science that does not renounce objectivity. Gramsci particularly criticized the scientist positions taken by the Bolshevik leader Nikolai Bukharin in Historical Materialism (1921) and the conference communication he delivered at the International Congress of History of Science and Technology in London in 1931. Gramsci did not avoid, at least implicitly, engaging with the theses of Lenin's Materialism and Empiriocriticism (1909). Gramsci's reception of these Russian positions was twofold: on the one hand, he agreed with the centrality of praxis (and politics) for a correct assessment of the meaning of epistemological positions; on the other hand, he disagreed with the reduction of the problem of epistemology to the dichotomy of materialism and idealism at the expense of any consideration of the ideological dimension of science.
\end{abstract}

Keywords: Gramsci's political epistemology; Lenin's Materialism and Empiriocriticism; Bukharin's epistemology; Marxist STS; political objectivity 
C’è quindi una lotta per l'oggettività [...] e questa lotta è la stessa lotta per l'unificazione culturale del genere umano

(There is . . . a struggle for objectivity ... and this struggle is the same struggle for the cultural unification of the human race).

Antonio Gramsci, Quaderni del carcere (Prison Notebooks), 1932-1933¹

\section{Introduction}

The question of objectivity-once solely an issue for philosophers and epistemologists- has recently become one of the most controversial political issues. ${ }^{2}$ In an age of post-truth populisms, appeals to objective facts or, on the contrary, the denial of the same, occupies environmental activists as much as journalists and politicians. ${ }^{3}$ Classical topoi of the history and philosophy of science-the genesis and development of scientific facts, and the problem of the social and economic roots of scientific knowledge—are now debated outside the circle of academic insiders. ${ }^{4}$ The task of securing the reliability of scientific analyses and the consequences of the facts they establish is not only a speculative philosophical concern anymore. ${ }^{5}$ Former champions of social constructionism, now persuaded of the importance of an "evidence-based policy," have

${ }^{1}$ Antonio Gramsci, Quaderni del carcere [Prison Notebooks], ed. Valentino Gerratana, Edizione critica dell'Istituto Gramsci (critical edition of the Istituto Gramsci) (Turin: Einaudi, 2007), Notebook ("quaderno"; hereafter Q.) 11, $\$ 17,1416$. Unless otherwise noted, all translations are my own.

2 The entire debate surrounding fake news and propaganda has taken on a genuinely epistemological character. There are countless examples on the internet. Vis-à-vis the outbreak of the coronavirus pandemic in the United States, the editor of The New Yorker, David Remnick, gave an article the title "Trump, Truth, and the Mishandling of the Coronavirus Crisis." David Remnick, "Trump, Truth, and the Mishandling of the Coronavirus Crisis," The New Yorker, March 15, 2020, https://www.newyorker. $\mathrm{com} /$ news/daily-comment/trump-truth-and-the-mishandling-of-the-coronavirus-crisis (accessed on 22 March 2020). The editorial begins by making a connection between the belief in the "responsibilities of government" and "the realities of fact."

${ }^{3}$ A democratic turn, tendentially leftist, in the appreciation of facts by sociologists of science has resulted from the debates on the climate crisis, in which it is imperative to counter climate change denialists. See Naomi Oreskes and Erik M. Conway, Merchants of Doubt: How a Handful of Scientists Obscured the Truth on Issues from Tobacco Smoke to Global Warming (London: Bloomsbury, 2012).

${ }^{4}$ The loci classici for these themes are, of course, Ludwik Fleck, Genesis and Development of a Scientific Fact (Chicago: University of Chicago Press, 1979); Boris Hessen, "The Social and Economic Roots of Newton's Principia," in Science at the Cross Roads. Papers presented to the International Congress of the History of Science and Technology held in London from June 29th to July 3rd, 1931, by the delegates of the U.S.S.R., 147-212 (London: Kniga, 1931). Cf. Claus Zittel, "The Politics of Cognition: Genesis and Development of Ludwik Fleck's 'Comparative Epistemology,'” in Science as Cultural Practice, eds. Moritz Epple and Claus Zittel, vol. 1, Cultures and politics of research from the early modern period to the age of extremes, 183-199 (Berlin: Akademie Verlag, 2010); Gideon Freudenthal and Peter McLaughlin, eds., The Social and Economic Roots of the Scientific Revolution: Texts by Boris Hessen and Henryk Grossmann (Dordrecht: Springer, 2009).

5 Eleonora Montuschi, “Using Science, Making Policy: What Should We Worry About?," European Journal for Philosophy of Science 7, no. 1 (2017): 57-78. 
publicly recanted the positions they took in the so-called "Science Wars" of the 1990 s. $^{6}$ At that time, reactionary defenders of (pure) science reacted to "impure" theories of science which radical sociologists of science conceived as a social construction. The defenders of science feared that too much sociology could legitimate (postmodern) relativism and discredit science. ${ }^{7}$ In their eyes, the alliance of constructionism and relativism might in turn foster multiple kinds of pseudo-knowledge. Under the pretext of fighting against such illegitimate consequences, self-proclaimed champions of reason dismissed all radical forms of critical and emancipatory thought-beginning with feminist epistemology and postcolonial studies-with the allegation that they constitute the postmodern fellow-travelers of "pseudo-science."

Today, the situation is different. Social constructionism, far from being the expression of an "overcritical" leftist tendency in science studies, has become a repository for conceptual tools and arguments that social Darwinists can employ to propagate their Machiavellian vision of truth (or "post-truth") which they deem to coincide with the reason of the stronger. Truth, they argue, depends on socio-political factors such as the control of mass media, power strategies linked to economic, even military, interests, and fundraising. ${ }^{9}$

While the alternative between "scientism" (understood as the uncritical acceptance of the conclusions of science) and the "ideology" of interest-guided science stands in the way of science studies as a seemingly insurmountable obstacle, reality has anticipated theory. The coronavirus crisis of 2020 has made biopoliticians' conspiracy theories about the construction of a state of emergency around a "tame" virus appear ludicrous. ${ }^{10}$ At the same time, the social capital of professional scientists and physicians has exponentially grown; their public reputation is magnified by their role as the most reliable political advisors, the only ones who seem to be capable of reasonable intervention strategies. Scientists' advice has even silenced or redirected the most restless among populist leaders, those who attempted to downplay the severity of the

\footnotetext{
${ }^{6}$ Bruno Latour, "Why Has Critique Run out of Steam? From Matters of Fact to Matters of Concern," Critical Inquiry 30, no. 2 (2004): 225-48. For an overview of "constructionist" approaches, see Jan Golinski, Making Natural Knowledge: Constructivism and the History of Science with a New Preface (Chicago: University of Chicago Press, 2011).

7 Ullica Segerstråle, Beyond the Science Wars: The Missing Discourse about Science and Society (Albany: State University of New York Press, 2000).

8 Alan D. Sokal, Beyond the Hoax: Science, Philosophy and Culture (Oxford: Oxford University Press, 2010). See also Alan Sokal and Jean Bricmont, Impostures intellectuelles (Paris: Jacob, 1997). Note the Popperian echoes of Sokal's "liberal-conservative" defense of science against "pseudo-science and irrationalism."

9 Steve Fuller, Post-Truth: Knowledge as a Power Game (London: Anthem Press, 2018); Pietro Daniel Omodeo, "The Political and Intellectual Entanglements of Post-Truth: A Review of Steve Fuller's PostTruth: Knowledge as Power Game,” Public Seminar (September 18, 2019), http://www.publicseminar. org/2019/09/the-political-and-intellectual-entanglements-of-post-truth/.

10 See "Coronavirus and Philosophers," European Journal of Psychoanalysis, accessed March 24, 2020, http://www.journal-psychoanalysis.eu/coronavirus-and-philosophers/.
} 
infection and avoid any measures to contain an economically inconvenient virus. ${ }^{11}$ However, the triumph of scientific politics in a moment of the necessary suspension of basic civil rights and common law poses serious questions about democracy, because it resuscitates the concerns over technocratic governance and balancing two opposing tendencies inherent to democracy: the call for more experts' governance, on the one hand, and the desire for more participatory politics, on the other. ${ }^{12}$ The dichotomy between culture and science reemerges, but in a different fashion.

Some scholars have recently questioned the separation of an either-or alternative between cultural values and scientific facticity by pointing to a historicist escape from the politicalepistemological dilemma. A reactivation of the legacy of Marxist thinkers such as the young György Lukács and Antonio Gramsci seems to be particularly desirable. Both argued that the historicity of all knowledge does not exclude its objectivity, despite the fact that no extrasubjective positioning is ever possible. Objectivity is not a fixed standard that can be grasped sub specie aeternitatis, but, instead, it always appears in its cultural making. Gramsci stressed the ideological character of the natural and social sciences alike, but he also emphasized how such knowledge is a consequence of objective transformation. ${ }^{13}$

In this essay I present some reflections on Gramsci's epistemology, in particular his viewpoints on the connection between historical subjectivity and scientific objectivity. I see this reflection as a necessary follow up to my recent discussion of the political-epistemological relevance of a Gramscian approach for the open challenges of historical epistemology. As I have argued in my book on Political Epistemology (2019), the strength of this approach rests in the call for historical self-reflection as a means of comprehending the ideological component of any discourse on science and as a premise for political positioning in matters of culture, including

${ }^{11}$ In March 2020, US President Trump still claimed "WHO's global death rate 'a false number'," one week or so before US American cities eventually began to be locked down as had already occurred in large regions of Asia and Europe (Joanna Walters, Lauren Aratani, and Peter Beaumont, "Trump calls WHO's global death rate from coronavirus 'a false number'," The Guardian, March 5, 2020, accessed March 24, 2020, https://www.theguardian.com/world/2020/mar/05/trump-coronavirus-who-globaldeath-rate-false-number).

${ }^{12}$ The classic reference is Jürgen Habermas, "Technology and Science as 'Ideology,"” in Toward a Rational Society: Student Protest, Science, and Politics, 81-122 (Boston: Beacon Press, 1970). On the relevance of critical theory for Science, Technology, and Society studies with respect to the problems that technocracy and technological rationality pose to democracy, see Andrew Feenberg, "Critical theory of technology and STS," Thesis Eleven 138, no. 1 (2017): 3-12.

${ }^{13}$ Christoph Henning, "The Politics of Nature, Left and Right: Comparing the Ontologies of Georg Lukács and Bruno Latour," in Georg Lukács and the Possibility of Critical Social Ontology, ed. Michael J. Thompson, 289-317 (Leiden; Boston: Brill, 2020). I am very thankful to Andrew Feenberg for sharing with me a manuscript essay of his on precisely these issues. 
science and the discourses thereupon. ${ }^{14}$ In Gramsci's conception, theory and history are closely interwoven in the framework of a praxis-oriented philosophy of culture. I view his commitment to always maintain the connection between the subjective dimension of history (collective agency) and its material basis (the socio-economic component) as a viable path that leads away from the untenable dichotomies of current epistemology. Subaltern scholars have claimed that this Gramscian juncture of the intellectual and the material contains the potential for an emancipatory dynamization of social and political positioning. ${ }^{15}$ However, I view the Gramscian juncture as a suitable instrument for the comprehension and overcoming of the subjectivity-objectivity alternative posited by two contradictory tendencies in historical epistemology, namely structuralist objectivity and postmodern subjectivity. ${ }^{16}$ Both approaches have their virtues, as they help to overcome static conceptions of science in the history and philosophy of science, but neither meets the complexity of today's political challenges because they either conceive of historical epistemology as an objective process without subject, thus obscuring the political, or as an almost purely subjective endeavor, thus marginalizing materiality. We need both: subjective agency and materiality. I claim that these two components form a politically mature historical epistemology, one that can successfully overcome the onesidedness of "positivism" by integrating its realism within a praxeological understanding of reality—a developmental reality, in which subjectivity and objectivity interact.

The opposition between scientism (call it "positivism") and relativism (call it "postmodern") is a dialectical trap because it creates the illusion of the necessity to choose between two positions that, as a matter of fact, sustain each other. On this point Gramsci is again a useful interlocutor, but not if his views are taken in isolation. His emphasis on culture as a key aspect of the historical process offers important insights into science as a cultural and historical phenomenon (or better to say, a "cultural-political" historical phenomenon) but runs the risk of disembodied

14 Pietro Daniel Omodeo, Political Epistemology: The Problem of Ideology in Science Studies (Cham: Springer, 2019). Until now, my political-epistemological reflection has concentrated on cultural criticism of the implicit and explicit agendas of science studies: past and current academic discourses on science, in particular historical, philosophical and sociological ones. The interlocked problem of objectivity and materiality has remained at the margins of my discussion, but it needs to be explicitly addressed because only a historical understanding of knowledge, which is able to include the question of objectivity and materiality, can constitute a response to our dilemma.

15 See the reflection on subalternity as "a position without identity" in Gayatri Chakravorty Spivak, "Scattered Speculations on the Subaltern and the Popular," Postcolonial Studies: Culture, Politics, Economy 8, no. 4 (2005): 475-86.

16 Pietro Daniel Omodeo, "Soggettività, Strutture, Egemonie: Questioni Politico-Culturali in Epistemologia Storica," Studi Culturali 15, no. 2 (2018): 211-34. In previous discussions, I focused on the (post)structuralist and postmodern vistas in political epistemology by Hans-Jörg Rheinberger, Toward a History of Epistemic Things: Synthesizing Proteins in the Test Tube (Stanford: Stanford University Press, 1998); Lorraine Daston and Peter Galison, Objectivity (Cambridge, Mass: MIT Press, 2018). Cf. Thomas Sturm and Uljana Feest, eds., What (Good) Is Historical Epistemology? (Dordrecht: Springer, 2011). 
idealization if it is conceived in separation from materiality. Postmodern readings of Gramsci have taken this blind alley. They have exaggerated Gramsci's idealistic bias to the point of affirming that the ultimate constituent of human reality is rhetoric. ${ }^{17} \mathrm{I}$ disagree with this, both regarding the postmodern reading of Gramsci and its political and epistemological consequences. I deem it important to reassess Gramsci's conceptions in a critical manner, as the expression of a historicist, culturalist but not idealist position. Only in this manner, I argue, can his ideas be valued as useful means to engage with the open problems of the present.

In the discussion of science in his Prison Notebooks, Gramsci confronted the following problems: the historicity of knowledge, its political meaning, the ideological and praxeological problems of objectivity and subjectivity, the relevance of facts and the cultural importance of scientific theories, the contrast between materialist and idealist worldviews, and the dangers of relativism as well as those of scientism. He did so because these topics were at the center of the philosophical debates of his day. He particularly reacted to and integrated the Marxistspecifically Soviet—debates on science, including over the foundations of science and history. I argue that although Gramsci rejected the scientism of prominent Soviet intellectuals such as Nikolai Bukharin, he did renounce objectivity, which he re-defined in opposition to Bukharin. By doing so, Gramsci also took distance from Lenin's epistemology in significant ways but did not discard his conception as a whole. Instead, I claim that he freed the praxeological potential of Lenin's philosophy from its scientist remnants, especially in matters of science and culture.

In this essay I begin with an assessment of the reappraisal of Gramsci's views on science for the history, philosophy and sociology of science. I then consider his position as one of the voices of the heated debates on the status of science and its relation to politics among Marxists in the 1920s and 1930s, decades which are marked both by the flourishing and suppression of leftist culture. Gramsci's historicist approach to cultural facts and politics is reflected in his views on science as a cultural phenomenon. His stress on subjectivity and praxis gave the impression that he neglected materiality and objectivity. By contrast, I argue that he did not renounce but revised the concept of objectivity from a praxeological perspective, according to which the objectivity of science especially rests in its power to transform the world. He developed this viewpoint in reaction to crude scientism. I will present Gramsci's philosophy and sources of inspiration but also discuss the path to objectivity laid out in Lenin's Materialism and Empiriocriticism. I argue that Gramsci accepted Lenin's idea that epistemology and the problem of objectivity are political issues, but that he also rejected the scientist bias that affected Lenin's reduction of epistemological problems to an either-or ontological choice between materialism and idealism.

17 Ernesto Laclau has addressed a postmodern reading of Gramsci in relation to social ontology, but the epistemological meaning of Gramsci's thought extends, in my view, beyond the social and political. Cf. Ernesto Laclau, On Populist Reason (London; New York: Verso, 2007); Ernesto Laclau and Chantal Mouffe, Hegemony and Socialist Strategy: Towards a Radical Democratic Politics (London: Verso, 2001). 


\section{State of the Art: Gramsci and History and Philosophy of Science}

In view of the challenges currently faced by historians and philosophers of science, it is no surprise that Gramsci's general conception of the entanglements of science, ideology and society has received increasing attention. Specific studies have offered detailed analyses of the pages on science that he wrote while he was a political prisoner of the Fascist regime. ${ }^{18}$ His prison Notebook 11, which was penned between 1932 and 1933, includes some of his most relevant observations on science, although they take the form of a specific criticism of the scientist theses of the Bolshevik cultural leader, Nikolai Bukharin. ${ }^{19}$ Apart from its prosopographic value, Gramsci's notebook contains novel research perspectives and conceptual tools. $\mathrm{He}$ inspired leftist scholars who sought to escape the scientist tendencies within Marxism, but who also did not want to renounce a constructionist engagement with the sciences. These scholars applauded Gramsci's attack on the kind of reductionist explanations of history, which typically come from those who consider culture to be the necessary outcome of physics, biology, and a positivist sociology or economy. Intellectuals as diverse as the philosophy and science historian, Eugenio Garin, the anti-positivist sociologist, Zygmunt Bauman, and the Marxist historian, Eric Hobsbawm, all shared this appreciation of Gramsci. ${ }^{20} \mathrm{~A}$ host of scholars in cultural and literary studies have drawn important methodological and critical insights from Gramsci's cultural Marxism. ${ }^{21}$ His legacy in the history and philosophy of science is also remarkable.

\footnotetext{
18 The most updated reconstruction of the evolution and context of Gramsci's thought in the years of his imprisonment is by Giuseppe Vacca, Vita e pensieri di Antonio Gramsci: 1926-1937 (Turin: Einaudi, 2012).

19 Among the contributions on Gramsci and the sciences, see Marina Palladini Musitelli, ed., Gramsci e la scienza: Storicità e attualità delle note gramsciane sulla scienza (Trieste: Istituto Gramsci del Friuli Venezia Giulia, 2008); Pietro Daniel Omodeo, "La via gramsciana alla scienza," Historia Magistra 4 (2010): 53-68; Francesca Antonini, "Science, History and Ideology in Gramsci's Prison Notebooks," HoST - Journal of History of Science and Technology 9 (2014): 64-80. For the present discussion on objectivity, see Antonio Di Meo's essay, "L'oggettività del reale': Riflessioni gramsciane su scienza e realismo fra programma nazionale e cosmopolitismo," in Musitelli, Gramsci e la scienza, 109-46.

${ }^{20}$ Eugenio Garin, Con Gramsci (Rome: Editori Riuniti, 1997); Zygmunt Bauman, Zarys marksistowskiej teorii spoteczeństwa (Warsaw: PWN, 1964); Eric Hobsbawm, How to Change the World: Reflections on Marx and Marxism (New Haven: Yale University Press, 2011), 334-343.

${ }^{21}$ One ought to at least mention here: Raymond Williams, Marxism and Literature (Oxford: Oxford University Press, 1977) and Stuart Hall, "Cultural Studies: Two Paradigms," Media, Culture and Society 2, no. 1 (1980): 57-72.
} 
He has exerted a decisive influence on historians of science who use a cultural-political framework to critically interpret science, ideology, and related issues (e.g., the political uses and abuses of science, the public role of scientists as intellectuals, science popularization, and education)..$^{22}$

Furthermore, the Gramscian theory of hegemony has proven to be an important instrument for the comprehension of science as culture. The theory of hegemony stresses the relevance of direction in politics (or political leadership) and cultural politics, and it reveals the construction of consensus and consciousness by means of ideology. Gramsci did not conceive these cultural and psychological dimensions of politics in idealistic terms (i.e., as the primary -if not onlysource of social ontology), although postmodern Gramscian theorists of populism have given the opposite interpretation of his thought by overemphasizing the constituency of values and identities. ${ }^{23}$ Instead of viewing ideology as a discursive genesis of social ontologies, he regarded it as dialectically connected with the structural basis of human interrelations, since collectively shared conceptions transform the social and human reality both materially and intellectually. Clashes over identities and values are an essential part of societal dynamics; they are rooted in socio-economic relations without being determined by them. To sum up this line of thought, Gramsci assumes that ethical-political motivations and consciousness shape society as much as they are shaped by its socio-economic structures. This dialectical conception fosters a political perspective that analyzes the facts of culture, including science, which, at this point, should be understood as a collective endeavor at the intersection of the material and the spiritual needs of human collectivities. The Gramscian historian combines structural analysis and political comprehension without subordinating one element to the other. ${ }^{24}$ In a sense, Gramsci's theory of hegemony and his "philosophy of praxis" constitute a synthesis avant la lettre of structuralist and constructionist approaches to intellectual advance. Thus, a sociopolitical historiography that is informed by Gramscian categories can contribute to a renewed historical-epistemological reflection: the articulation of a political epistemology that addresses

${ }^{22}$ Roger Cooter, The Cultural Meaning of Popular Science: Phrenology and the Organization of Consent in Nineteenth-Century Britain (Cambridge: Cambridge University Press, 1984), Roger Cooter and Stephen Pumfrey, "Separate Spheres and Public Places: Reflections on the History of Science Popularization and Science in Popular Culture," History of Science 32, no. 3 (1994): 237-267, and Agustí Nieto-Galan, "Antonio Gramsci Revisited: Historians of Science, Intellectuals, and the Struggle for Hegemony," History of Science 49, no. 4 (2011): 464-467. A collection of essays making use of Gramscian categories for the history of science is forthcoming: Massimiliano Badino and Pietro Daniel Omodeo, eds., Cultural Hegemony in a Scientific World: Gramscian Concepts for the History of Science, in the series Historical Materialism (Leiden: Brill, 2020).

${ }^{23}$ Laclau, On Populist Reason, 11 mentions "Rhetorical operations . . . constitute broad popular identities ... they actually constitute populist subjects ..." and: "Populism is the royal road to understanding . . . the ontological constitution of the political as such" (Ibid., 67).

${ }^{24}$ Pietro Daniel Omodeo, "Socio-Political Coordinates of Early-Modern Mechanics: A Preliminary Discussion," in Emergence and Expansion of Preclassical Mechanics, eds. Rivka Feldhay, Jürgen Renn, Matthias Schemmel, and Matteo Valleriani, 55-78 (Cham: Springer, 2018). 
the juncture between science, society, ideology, history, and politics. ${ }^{25}$ Today, it is particularly urgent to reconsider the problem of the materiality and objectivity of the sciences, a topic which is latent in Gramsci's discussion of the sciences and their socio-political a priori. Because the Marxist debates of the 1930s discussed these topics at length they provide an essential point of departure for our reassessment of the issues at stake, in Gramsci's thought and beyond.

\section{Marxist History and Philosophy of Science in the Dramatic 1930s}

The 1930s represented a high-water mark in the codification of a Marxist approach to the history and philosophy of science. The intervention of a group of Soviet delegates at the Second International Congress on the History of Science and Technology in London, from June 29 to July 3,1931, is considered to be the decisive moment for the establishment of a Marxist history of science. ${ }^{26}$ More generally, it marked Marxism's entrance into the field of the sociology of science (or, more precisely, the sociological history of science) because it emphasized the socioeconomic roots and the social function of scientific knowledge. It was the beginning of what soon came to be known as "externalism," one of the most influential paradigms in science studies in the short twentieth century. In the years of the Cold War, "externalism" was often seen as the socialist paradigm that was opposed to the "internalism" of those who viewed science as a purely intellectual endeavor (either technical or speculative). The latter disembodied view upon science prevailed in Anglo-American History and Philosophy of Science (HPS) west of the Iron Curtain. ${ }^{27}$

The lecture "The Socio-Economic Roots of Newton's Mechanics" (1931), which was presented in London by the physicist Boris Hessen, has become a classic —-though controversial—work in the history of science. ${ }^{28}$ It introduced the original concept of "socio-economic roots," which invited scholars to look at the broad societal factors that account for the development of the

\footnotetext{
25 Omodeo, Political Epistemology.

${ }^{26}$ Cf. Joseph Needham, Foreword to Science at the Cross Roads: Papers Presented to the International Congress of the History of Science and Technology held in London from June 29th to July 3rd, 1931, by the delegates of the U.S.S.R., vii-x (London: Frank Cass, 1971). See also Freudenthal and McLaughlin, The Social and Economic Roots of the Scientific Revolution.

27 Pietro Daniel Omodeo, "After Nikolai Bukharin: History of Science and Cultural Hegemony at the Threshold of the Cold War Era," in "Social and Human Sciences on Both Sides of the Iron Curtain," eds. Ivan Boldyrev and Olessia Kirtchik, special issue, History of Human Sciences 29, no. 4-5 (2016): 13-34. 28 Floris Cohen, The Scientific Revolution: A Historiographical Inquiry (Chicago: The University of Chicago Press, 1994), 329: "what has both famously and infamously become known since as the 'Hessen thesis' comes down to the argument that, through the mediation of technological developments, the emergence of early modern science is to be explained by the needs of early capitalism."
} 
sciences independently of the subjective perception of the scientists involved in the collective enterprise of knowledge. ${ }^{29}$

On his part, Bukharin, who was the leader of the Soviet delegation in London, opened the speeches of his group with the programmatic lecture "Theory and Practice from the Standpoint of Dialectical Materialism." This paper was the first to be included in the rapidly issued Science at the Cross Roads: Papers Presented to the International Congress of the History of Science and Technology held in London from June 29th to July 3rd, 1931 by the Delegates of the U.S.S.R. Bukharin's essay, like those of the other communist delegates, was marked by the frequent use of Marxist concepts that were skeptically received by the academic public. As the British crystallographer, John D. Bernal, remarked, "their appeal to dialectic, to the writings of Marx and Engels, instead of impressing their audience, disposed them not to listen to the arguments which followed." ${ }^{30}$ It was the beginning of the Cold War "incommensurabilities": its divergent cultural and political standpoints, which reflected the opposite economic-political projects hegemonized by the USA and the USSR.

The 1930s was a fecund time for Marxist debates in the history of science in other contexts as well. The Frankfurt Institute for Social Research fostered a Marxist-inspired debate on science that sparked a controversy between Franz Borkenau and Henryk Grossmann over the correct assessment of the connection between society, technology, and modern science. In his book Der Übergang von feudalen zum bürgerlichen Weltbild (The Transition from the Feudal to the Bourgeois Worldview) (1934), Borkenau tried to directly derive modern mechanics from the labor conditions of capitalism. Max Horkheimer, who regarded his analysis as rough and simplistic, commissioned a critical review from Grossman. The result was a lengthy essay entitled Die gesellschaftlichen Grundlagen der mechanistischen Philosophie und die Manufaktur (The Social Foundations of Mechanistic Philosophy and Manufacture) (1935). Grossman reprimanded Borkenau for his lack of historical accuracy and his schematic application of Marx's periodization of history, and accused him of an insufficient historical and social analysis of early capitalism. More importantly for the history of science in general, Grossman brought forward the thesis that the emergence of modern mechanics depended on the development of machine technology, a thesis that is consonant with Hessen's conception of the rise of modern physics as a result of socio-economic needs and technological conditions. ${ }^{31}$ Both Borkenau and Grossman's publications appeared in Paris despite the fact that they wrote in German.

${ }^{29}$ Cf. Rose-Luise Winkler, "Ein unveröffentlichtes Manuskript von Boris M. Hessen: 'Materialien und Dokumente zur Geschichte der Physik', Sitzungsberichte der Leibniz-Sozietät 92 (2007): 133-152.

${ }^{30}$ John Desmond Bernal, The Freedom of Necessity (London: Routledge \& Kegan Paul, 1949), 338.

31 According to Gideon Freudenthal and Peter McLaughlin, the chain of causes, according to the Hessen-Grossman thesis, can be summarized as follows: "economics . . . present[s] demands, which pose technical problems, which generate scientific problems.” In Freudenthal and McLaughlin, The Social and Economic Roots of the Scientific Revolution, 4. 
National-socialism had already overtaken Germany and forced dissident intellectuals and Jews to emigrate.

The "fabulous" decade of the 1930s ended with the publication of another seminal text of the Marxist approach to the sociology of science: John D. Bernal's The Social Function of Science (1939). This book, which has been reprinted countless times, still constitutes a reference point in the studies on Science, Technology, and Society (STS). It raised questions concerning the links between science and the economy, the war industry and politics, citizenship and propaganda, as well as between nationalism and technology, questions that still possess a striking actuality. The hegemonizing capacity of the Marxist reflection on science from those years can be measured by the fact that even those scholars who would later become champions of anti-communist lines of inquiry could not avoid their opponents' theses. This insight applies above all to the Weberian sociologist of science, Robert K. Merton, whose Science, Technology and Society in Seventeenth Century England (1938) significantly references Hessen's essay on Newton. The part of his work inspired by Soviet historians of science especially concerns the connection between physics and technology, a debt that the young Merton was still naive enough to state explicitly. ${ }^{32}$ In the wake of the 1940 s and the enlargement of the ideological divides of the Cold War, US intellectuals developed counter-cultural lines that programmatically banned any positive references to Marxist historiography and epistemology, as both the affirmations and the silences of scholars like James Conant and Alexandre Koyré, as well as their pupil, Thomas Kuhn, attest. ${ }^{33}$

The intellectual conditions that made possible the emergence and the flowering of Marxist debates on science were erased in the same decade that this tradition came to fruition. Most of the Soviet delegates that attended the London Congress did not survive Stalin's purges. At the 1971 Moscow Congress on the History of Science and Technology, the British historian of Chinese science, Joseph Needham, lamented the losses. His own research was fueled by the inspiration he received from Soviet thinkers in 1931. Forty years later, he mourned the "tragic fact of the disappearance of so many of these delegates in the years after the Congress, according to the dreadful principle that 'all revolutions devour their own children'." ${ }^{34}$ Bukharin's own trial had been a tragic display of brutal power, as it was justified by a forced confession. ${ }^{35}$ Hessen had disappeared even earlier, in 1936, leaving unpublished an anthology of sources on the socio-

32 Robert K. Merton “Science, Technology and Society in Seventeenth Century England," Osiris 4 (1938): 360-632.

33 Omodeo, Political Epistemology, esp. 84-91.

${ }^{34}$ Needham, Foreword to Science at the Cross Roads, ix.

35 Stephen F. Cohen, Bukharin and the Bolshevik Revolution: A Political Biography 1888-1938 (New York: Knopf, 1971). 
economic history of the scientific revolution. ${ }^{36}$ The Frankfurt Institute for Social Research was dispersed by the Nazis. Grossman, like Max Horkheimer and Theodor Adorno, had to emigrate to the United States. Walter Benjamin could never reach them on the other side of the Atlantic, and committed suicide in 1940 after his flight from occupied France was blocked the border with Spain. Austria, which had been a focal point of historical-philosophical inquiries into science, was hit hard by the wave of extreme-right politics. Moritz Schlick, the logical empiricist, was murdered in 1936 on the stairs of the University of Vienna by one of his own students, a right-wing extremist mythomaniac. The intellectuals of the Vienna Circle, many of whom were socialists or communists, were dispersed after the Anschluss of Austria to the Third Reich in $1938 .{ }^{37}$ Among them, Edgar Zilsel is probably best known in the history of science for his Marxist reconstruction of the social roots of the modern scientist. ${ }^{38} \mathrm{He}$ emigrated to the USA, where he published his most renowned contributions to the socialist historiography of science before eventually committing suicide in 1944. The Polish Jewish immunologist and "historical epistemologist," Ludwik Fleck, survived the concentration camps, but the cultural devastation produced by Nazism and World War II grossly deferred the reception and appreciation of his most original contribution to the sociology and mentalities of science, Entstehung und Entwicklung einer wissenschaftlichen Tatsache (Genesis and Development of a Scientific Fact) (1935). ${ }^{39}$

Antonio Gramsci did not survive the 1930s. His fragile body could not resist the hardships of the Fascist prisons, and he died in 1937. His most important pages on epistemology and science were written in the isolation of his cell. They were meant as a distant contribution to the ongoing international debates among Marxist philosophers and historians of science.

\footnotetext{
36 Winkler, "Ein unveröffentlichtes Manuskript." See also Winkler, An den Ursprüngen wissenschaftssoziologischen Denkens: Erstes Drittel des XX. Jahrhunderts (Russland/Sowjetunion) (Berlin: trafo Wissenschaftsverlag, 2013).

37 For a recent discussion of the dramatic consequences of Nazism on the Austrian-German epistemological and scientific tradition, see Fynn Ole Engler and Jürgen Renn, Gespaltene Vernunft vom Ende eines Dialogs zwischen Wissenschaft und Philosophie (Berlin: Matthes \& Seitz, 2018).

${ }^{38}$ Edgar Zilsel, "The Sociological Roots of Science," Social Studies of Science 30, no. 6 (2000): 935-939 (originally published elsewhere in 1942). Cf. Pamela O. Long, Artisan/Practitioners and the Rise of the New Sciences, 1400-1600 (Corvallis: The Oregon State University Press, 2011), 11-22.

${ }^{39}$ Cf. Zittel, "The Politics of Cognition."
} 
The most famous pages of the Notebook 11 have the form of a criticism of the scientist positions held by Bukharin, in particular those presented in the latter's popular introduction to Marxism, Historical Materialism (1921), and in his lecture at the London Congress of the History of Science and Technology (1931). ${ }^{40}$

In the following subsections, I discuss Gramsci's views on science, politics, history and society, which I would label as his own path towards a "historical-political epistemology." I read his culturalist comprehension and criticism of science and scientism against the background of the Marxist debates on science that culminated in the 1930s. Since Lenin's work in philosophy of science, in particular his attack against Machism and idealism in Materialism and Empiriocriticism, deeply influenced the Russian and international debates on this topic, I delve into Gramsci's critical engagement with his theses. I argue that his Notebook 11, in which he expanded on problems of science and scientific culture, was not only directed against Bukharin but also against a certain line of reception of Lenin's thought. ${ }^{41}$ Contrary to this strand, which saw history and Marxism as founded on positive science, Gramsci emphasized dialectics, culture and historicity, as the backbone of scientific thought, not vice versa. By doing so, he reactivated neo-idealistic ethico-political historiography against economic reductionism. This could raise the suspicion that Gramsci adhered to an idealistic form of Marxism, but in fact Gramsci aimed to elaborate on Leninist "philosophy of praxis" against the dogmatization of the results of science at a specific stage of its historical development. Owing to the theoretical implications of Gramsci's epistemology for issues related to realism and objectivity, I deem it expedient to discuss his material conception of ideology in some detail, in order to stress that his "constructionist" approach did not imply a disembodied conception of culture, nor an abstractly relativistic understanding of science and the world. In other words, Gramsci did not fall into the category that the Russian philosopher Mikhail Lifshitz once defined as follows:

\footnotetext{
40 The complex relation between Gramsci and Bukharin, which goes beyond the epistemological issue and also involves political and economic issues, has been discussed in the literature. The critical dimension of this reception-particularly in regards to science-has been done by Giuseppe Cospito (among others). See Giuseppe Cospito, "Il marxismo sovietico ed Engels: Il problema della scienza nel Quaderno 11," in Gramsci nel suo tempo, ed. Francesco Giasi, vol. 2, 747-65 (Rome: Carocci, 2008); Fabio Frosini, Gramsci e la filosofia: Saggio sui Quaderni del carcere (Rome: Carocci 2003), 103-104; and Peter Thomas, The Gramscian Moment: Philosophy, Hegemony and Marxism (Leiden-Boston: Brill, 2009), chap. 8.1. Valentino Gerratana has emphasized some aspects of continuity between Gramsci and Bukharin in Valentino Gerratana, "Presentazione," in Teoria del materialismo storico: Manuale popolare di sociologia marxista, by Nikolaj Ivanovic Bucharin, V-XXXVII (Florence: La nuova Italia, 1977). Cf. Michele Filippini, Una politica di massa: Antonio Gramsci e la rivoluzione della società (Rome: Carocci, 2015).

${ }^{41}$ It should be noted that Gramsci was not allowed to read Lenin's work in prison and was therefore forced to make reference to his works either by heart or indirectly. Cf. Palmiro Togliatti, "Il leninismo nel pensiero e nell'azione di A. Gramsci," in Studi gramsciani [1958], reprinted in Togliatti, La politica nel pensiero e nell'azione. Scritti e discorsi 1917-1964, ed. Michele Ciliberto and Giuseppe Vacca (Milano: Bompiani, 2014), 1133-1135.
} 
"relativism is dialectics for idiots." ${ }^{22}$ In my assessment, I also deal, albeit briefly, with Gramsci's Notebook 22, known for his considerations on "Americanism and Fordism," as it proves an important contribution, along his specific line of historico-political epistemology, to past and present debates on science, technology and society.

\section{The Idealistic Biases of Gramsci's Anti-Scientism}

As is shown in a letter written to his sister-in-law, Tatiana Schucht, Gramsci received Science at the Cross Roads (which he translated into Italian as "Scienza al bivio") in prison on August $31,1931 .{ }^{43}$ This text stimulated his reflections on the historical-epistemological problems that are connected to any substantial assessment of the natural sciences. In particular, Gramsci criticized Bukharin's Historical Materialism, which he knew quite well because he had used it for the cultural education of members of the Italian Communist Party ${ }^{44}$ At the beginning of Notebook 11, Gramsci objected that the education of militant communists should not begin with a criticism of academic philosophies, particularly idealism. Nor, in his opinion, could one use the natural sciences as the basis for a revolutionary philosophy of praxis that aims to create a new society. In fact, Gramsci claimed that both academic philosophy and the natural sciences are far removed from the worldviews that dominate the consciousness of the larger part of the population, which a revolutionary praxis would need to engage with. He held that common sense and religion are much more important vectors of ideological conformity and philosophical beliefs in society. ${ }^{45}$

To develop this argument, Gramsci engages with specific problems of science and criticized the improper extension of its methods to other fields, in particular political theory, history, and culture. In this regard, he accuses Bukharin of major theoretical errors, including a problematic scientism; the dogmatization of Marxism, which Bukharin incorrectly sees as an extension of the natural sciences; the fostering of a form of metaphysical materialism that is closer to common sense than to a critically reflective philosophy; following pseudo-positivistic objectivism; and

${ }^{42}$ Mikhail Lifshitz, Диалектика в истории искусства [Dialectics of the History of Art] [1927] in Collected Works, Vol. 1 (Moscow: Fine Arts, 1984), 223-240, p. 234: "Вообще релятивизм есть диалектика дураков."

${ }^{43}$ Gramsci to Tatiana Schucht, Prison of Turi, 31 August 1931, in Lettere dal carcere, eds. Sergio Caprioglio and Elsa Fubini, 473-475 (Turin: Einaudi, 1965), 474: "Proprio oggi è arrivato il libro inglese sulla Scienza al bivio."

${ }^{44}$ Andrea Catone, "Gramsci, Bucharin e la scienza," in Musitelli, Gramsci e la scienza, 81-108.

${ }^{45}$ One can especially find these pedagogical reflections expounded in the initial part of Gramsci's Notebook 11, the subsection of the "Appunti per una introduzione e un avviamento allo studio della filosofia e della storia della cultura" which is entitled "Alcuni punti preliminari di riferimento." In this subsection, Gramsci developed his reflections on spontaneous philosophy and the ideological interrelation of common sense, religion, and philosophy. Gramsci, Quaderni del carcere, Q. 11, \$12, 1373-1395. 
ascribing a sort of physical determinism to societal developments. In the following extract one can see how the conclusion of Bukharin's London speech holds a revealing rhetorical celebration of Marxism as the predictive and deterministic science of society that Gramsci castigates:

All knowledge is tested in practice, by experience. The same has to be said of the systematized knowledge of theory, theoretical tendency, "doctrine." It is relevant here to record, first of all, that Marxism, weighted in the balance of history, has been verified therein in the most varied directions. Marxism foretold the period of revolutions and the whole character of the epoch we are going through; Marxism foretold the dictatorship of the proletariat and the rise of a Socialist order; even earlier had been brilliantly justified the theory of the concentration and centralization of capital, etc. The Revolution has proved the great destroyer of fetishes, laying bare the fundamental links and interdependences of society in their real significance ... The Revolution has completely confirmed the theoretical teaching of Marx on the state. ${ }^{46}$

Such claims express a position that is diametrically opposed to Gramsci's conception of politics and culture as praxis. According to Gramsci, while historical circumstances are marked by a high degree of necessity, which can be "scientifically" investigated through the quantitative means offered by statistics and sociology, they are the outcome of a historical process that is never guaranteed and which, therefore, cannot be predicted. As Gramsci specifically noted:

it is only the struggle that can be predicted "scientifically" and not its concrete moments. These are the result of contrasting forces which are in continuous movement and can never be reduced to fixed quantities, because their quantity continuously becomes quality. One can [only] really "foresee" to the extent that one acts, makes a voluntary effort and therefore contributes concretely to creating the "foreseen" result. ${ }^{47}$

For Gramsci, the future has to be collectively constructed through joint efforts. Therefore, it cannot be conceived as the necessary result of an almost mechanical process, as Bukharin claimed. Such a conception hampers the revolutionary struggle as it hinders engagement and encourages a form of fatalism.

This polemic leads Gramsci to quite radical positions concerning science:

Actually, the very concept of science . . . ought to be critically destroyed; it is taken from the natural sciences as if they were the only science, the science par excellence in the positivistic meaning. ${ }^{48}$

\footnotetext{
${ }^{46}$ Nikolai Bukharin, "Theory and Practice from the Standpoint of Dialectical Materialism," in Science at the Cross Roads, 9-33 (London: Kniga, 1931), 28. Italics in the original.

${ }^{47}$ Gramsci, Quaderni del carcere, Q. 11, 1403.

${ }^{48}$ Ibid., Q. 11, \$15, 1404.
} 
This objection is directed against the hypostatization of one method and one model of science and its specific application to cultural-political history. Gramsci adds: "All research has its own specific method and builds its own specific science." ${ }^{49}$ In his criticism of those who consider the results of science to be absolute truths, Gramsci goes so far as to define "objectivity" as "humanly objective" and "historically subjective." ${ }^{\text {" }} \mathrm{He}$ deconstructs the concept of matter as well:

Matter should not . . . be considered as such, but insofar as it is socially and historically organized ... and thus natural science should be essentially considered a historical category, a human relation. ${ }^{51}$

Eventually, he emphasizes the internal connection, if not the identification, between science and ideology:

Despite all the efforts of scientists, science never presents itself as a bare objective notion; it always appears covered with an ideology. ${ }^{52}$

Science is an integral part of any worldview; in fact, the sciences are worldviews and, as such, are in competition with others. They are carriers of moral values and norms.

This array of conceptions and definitions were discussed and sometimes harshly criticized in the first years of the reception of Gramsci's Prison Notebooks. In a fundamental conference on Gramsci's legacy that was held in Rome in January 1958, the historian of philosophy, Eugenio Garin, stressed that "Gramsci exemplifies an entire cultural climate . . . in the limited attention given ... to 'scientists'." 53

\footnotetext{
${ }^{49}$ Ibid.

${ }^{50}$ Ibid., Q. 11, $\$ 17,1415-1416$.

${ }^{51}$ Ibid., Q. 11, $\$ 30,1442$.

52 Ibid., Q. 11, \$38, 1458.

53 Eugenio Garin, "Antonio Gramsci nella cultura italiana," in Studi gramsciani: Atti del convegno tenuto a Roma nei giorni 11-12 gennaio 1958, 3-14 (Rome: Editori Riuniti, 1958), 12. Eugenio Garin (1909-2004) has been one of the most influential historians of Renaissance philosophy in the previous century. His approach was deeply influenced by Gramsci's historical materialism and brought together the investigation of philosophy, science and culture. Apart from his extensive writings on the history of Italian philosophy, and on science and philosophy in the Renaissance, he also wrote on Gramsci's historicist philosophy. See, among others, Garin, Con Gramsci.
} 
Another prominent historian and philosopher of science, Ludovico Geymonat (a pupil of Giuseppe Peano, who had first embraced logical positivism and later switched to dialectical materialism), ${ }^{54}$ was even less delicate in arguing for Gramsci's limited understanding of science as having a status beyond the cultural:

Obviously this is not to deny the importance of Gramsci's thought ... but merely to decide whether-once this subject [the polemic with the Italian neoidealists] is abandoned - we can still find, and in what measure, the fundamental elements we need to solve the new philosophical problems of today in Gramsci's work. ${ }^{55}$

Mario Tronti, the father of the Italian Operaismo, anticipated Louis Althusser's criticism of Gramsci's identification of science with ideology because he claimed it might undermine not only the truth of the sciences but also the "scientificity" of Marxism itself. ${ }^{56}$ Both Tronti and Althusser viewed Gramsci's idea of Marxism as ideology, and science as a cultural phenomenon as contrary to a Leninist understanding of science. For them, objectivity is the necessary premise of scientific knowledge of nature and society. Given this opposition between Gramsci's culturalism and Lenin's scientificity, it is expedient to reassess Lenin's philosophy of science in order to better understand the debates and theoretical challenges surrounding Gramsci's theses.

\section{Gramsci on Science: between Russia and Italy}

Gramsci's culturally based arguments on science as ideology awoke the suspicion that he intended to revive idealistic positions similar to those that Lenin had castigated in Materialism and Empiriocriticism (1909). In fact, Lenin's book was a fierce defense of materialism against conventionalism, particularly against the Machist version of conventionalism, which had sparked a lively debate among Russians. Ernst Mach's empiriocriticism, a philosophy of science which emphasized the phenomenological and conventional character of scientific knowledge, was particularly popular among Russian Marxists. Lenin accused his comrades and

${ }^{54}$ Ludovico Geymonat (1908-1991) was a person of major intellectual reference for the history and philosophy of science in Italy. Among his many achievements, he directed a multi-volume history of philosophical and scientific thought, Storia del pensiero filosofico e scientifico (Milano: Garzanti, 19701972). Although his adherence to the theses of Lenin's Materialism and Empiriocriticism was at the basis of his depreciation of Gramsci's views on science, he highly appreciated Gramsci as a political thinker and communist leader.

55 Ludovico Geymonat, "Per un intervento al convegno di studi gramsciani," in Studi gramsciani: Atti (1958), 147-148, on 148.

56 Mario Tronti, "Alcune questioni intorno al marxismo di Gramsci," in Studi gramsciani: Atti (1958), 305-321. Tronti, a pupil of Galvano Della Volpe, founded the operaist journal Quaderni Rossi with Raniero Panzieri in the 1960s. His most influential work is probably Operai e capitale (Turin: Einaudi, 1966). On Althusser vis-à-vis Gramsci, see Thomas, The Gramscian Moment, chap. 1. Thomas calls the opposition between the structuralist and historicist approaches "the last great theoretical debate of Marxism.” 
fellow countrymen of undermining the reliability of science and fostering anti-materialistic positions. ${ }^{57}$ As he wrote, "Ernst Mach's doctrine that things are complexes of sensations is subjective idealism and a simple rehash of Berkeleianism." ${ }^{58}$

Gramsci knew about these debates and was able to partially follow them while in prison. For instance, he read Dimitrij Petrovič Mirskij's 1931 report in The Labour Monthly, which described the struggle between "mechanistic materialists," who were condemned by the Communist Academy in 1929, and the "dialecticians." ${ }^{59}$ However, Gramsci's approach to epistemology was massively influenced by Italian thinkers, particularly through his acquaintance with the critique of science from neoidealists such as Benedetto Croce and Giovanni Gentile, whom he critically reviewed. These philosophers even dismissed the philosophical value of science because they considered it to be a form of knowledge that was based on mere "pseudo-concepts." Gramsci took notes on these positions, for example on idealistic attacks against the "fortresses of objectivism" of those who consider "nature" and "world" to be "intangible realities," and consider knowledge "as a seeing instead of doing" (un "vedere" anziché un "fare"). ${ }^{60}$ Along these lines, Gramsci opposed the "scientific superstition" behind tendencies that attributed an almost metaphysical objectivity to natural knowledge in the framework of a mirror theory of the "external world." 61

Gramsci received from the Italian neoidealists of his day the positive evaluation of German classical philosophy: "Hegelian immanentism becomes historicism, but it is only absolute historicism from within the philosophy of praxis, absolute historicism, or absolute humanism." 62 Historicism, which Gramsci claimed "underlies all modern conceptions of life," ${ }^{63}$ only reaches its fulfilment with Marxist philosophy because it is self-conceived as "past and current history" (storia fatta o in fieri) ${ }^{64}$ Writing upon Croce, Gramsci points out that "the philosophy of praxis is the historicist conception of reality, which has been freed from any residue of transcendence and theology even in their last speculative incarnation; Croce's idealistic historicism still

57 Daniela Steila, Scienza e rivoluzione: La recezione dell'empiriocriticismo nella cultura russa (1877-1910) (Florence: Le Lettere, 1996). See also David Joravsky, Soviet Marxism and Natural Science, 1917-1932 (New York: Columbia University Press, 1961).

58 V. I. Lenin, Collected Works, vol. 14 (Moscow: Progress Publishers, 1962), 42.

${ }^{59}$ Dimitrij Petrovič Mirskij, “The Philosophical Discussion in the C.P.S.U. in 1930-1931,” The Labour Monthly 13, no. 10 (1931): 650-653, on 652. Cf. Gramsci to Tatiana Schucht, Turi, 3 July 1931, in Lettere dal carcere, 458-461, 459.

${ }^{60}$ Gramsci, Quaderni del carcere, Q. 10, $\$ 41.1,1296$.

${ }^{61}$ Ibid., Q. 11, \$39, 1458.

${ }^{62}$ Ibid., Q. 15, $\$ 61$, 1826-1827. Cf. Roberto Finelli, "Gramsci tra Croce e Gentile," Critica marxista 5 (1989): 77-92, and Fabio Frosini, "La crisi del marxismo nella critica di Gramsci a Benedetto Croce," in Tempi moderni: Gramsci e la critica dell'americanismo, eds. Giorgio Baratta and Andrea Catone, 92-100 (Rome: Edizioni Associate, 1989).

${ }^{63}$ Gramsci, Quaderni del carcere, Q. 16, \$9, 1860.

${ }^{64}$ Ibid., Q. 10, \$41, 1319. 
remains in the theological-speculative phase." ${ }^{65}$ Gramsci assumes the central thesis of Croce's Teoria e storia della storiografia (The Theory and History of Historiography), according to which "history is always contemporary history," adding the clause: "that is, politics." ${ }^{66}$ This addition implies the three-headed identification of history, politics, and philosophy, where philosophy means "a conception of the world that has become the norm of life." ${ }^{\prime 7}$

Another plausible source for Gramsci's arguments is the Hegelian interpretation of Marxism provided by the Italian neo-idealist Giovanni Gentile in La filosofia di Marx (The Philosophy of Marx) (1899).$^{68}$ In his younger years, which is to say before his allegiance to Fascism, reading Marx provided Gentile with a crucial concept: praxis. Gentile borrowed the expression "the philosophy of praxis" from Antonio Labriola, which was also an expression favored by Gramsci. ${ }^{69}$ Gentile explicitly writes that "the keystone of this philosophical conception [Marxism] lies in the concept of praxis" ${ }^{\text {"70 }}$ with a double reference to the preface of the Critique of Political Economy from $1859^{71}$ and the Theses on Feuerbach. ${ }^{72}$ Marx criticized "vulgar materialism" for it "considers the object, the sensible intuition, the external reality, as a 'given'

${ }^{65}$ Ibid., Q. 10, $\$ 8,1225$. Benedetto Croce (1866-1952), who was introduced to philosophy by Antonio Labriola, among others, developed a neo-Hegelian historicist approach that saw culture as the unfolding of four "spiritual" realms: aesthetic, logic, economy, and ethics. He was the founder of the journal $L a$ Critica, which constituted the intellectual organ around which the opposition to positivism gravitated. An important intellectual figure in the first decades of the twentieth century in Italy (also as Minister of Education, in 1920-21), he became the moral reference of opposition to Fascism as a defender of liberalism and liberal institutions. Gramsci especially derived from him the historicist approach and the attention to intellectuals and ideas as crucial actors of historical transformation against economic reductionism.

${ }^{66}$ Gramsci, Quaderni del carcere, Q. 10, \$2, 1241-1242.

${ }^{67}$ Ibid., Q. 10, \$ 17, 1255.

${ }^{68}$ Giovanni Gentile (1875-1944) was, together with Croce, the main representative of Italian neoidealism at the beginning of the twentieth century. His support for the Fascist regime marked a rupture of his friendship and intellectual collaboration with Croce. He entered the first Mussolini government and accomplished a school reform that granted a prominent role to philosophy and the humanities at the cost of education in the natural sciences. His support for Fascism went so far as to endorse the Nazibacked Repubblica Sociale Italiana in the last years of the World War II. Anti-fascist partisans executed him in Florence in the midst a war that turned into a civil war in 1944. On Gramsci's critical reception of Gentile, see Manuela Ausilio, "Giovanni Gentile: 'dignità Dello Spirito' e 'Gladiatorismo Gaglioffo,"” in Il Nostro Gramsci: Antonio Gramsci a Colloquio Con i Protagonisti Della Storia d'Italia, ed. Angelo D’Orsi, 339-50 (Rome: Viella, 2011).

${ }^{69}$ Antonio Labriola (1843-1904) was the philosopher who first introduced a theoretical and political discussion of Marxism in Italy, which he interpreted along a historicist and praxeological line of thought that inspired later generations of thinkers, particularly Benedetto Croce and Gramsci. Labriola held a chair of pedagogy in Rome, beginning in 1873, and was a correspondent of the main figures of European socialism of his day, including Friedrich Engels, Karl Kautsky, Karl Liebknecht, August Bebel, and Paul Lafargue.

${ }^{70}$ Giovanni Gentile, La filosofia di Marx: Studi critici (Florence: Sansoni, 1955), 72.

${ }^{71}$ Ibid., 61.

${ }^{72}$ Ibid., 65 and ff. Gentile included a translation of the Theses on Feuerbach. 
instead of a 'product'."73 Marx put forward the thesis that "reality . . . is a subjective production of man, namely a production of sense-activity (sinnliche Tätigkeit), not of thought, as Hegel and the other idealists believed." ${ }^{\prime 7}$ This interpretation is consonant with Gramsci's, as far as the references used by both thinkers are concerned (the preface to the Critique of Political Economy and the Theses on Feuerbach), as well as in its content: an "activistic" and dynamic vision of reality that indissolubly connects knowledge with praxis.

Although Gramsci embraced the neo-idealistic critics of scientism he did not reject science tout court or dismiss its cultural and philosophical value. Instead, idealistic arguments served to bolster Gramsci's attack against Bukharin's reduction of history and historical materialism to a positive science. The question for scholars interested in the legacy of these debates is now to ask whether Gramsci, by taking this position, was also distancing himself from Lenin's epistemological theses.

\section{On Lenin's Epistemology}

Lenin, who saw epistemology as a genuinely political field of inquiry, reduced the issue to a choice between materialism and idealism, which he regarded as expressions of a leftist philosophy versus a reactionary one, respectively. His Materialism and Empiriocriticism was a crude reprimand to the work of Mach's Marxist followers, especially in Russia. He argued that empiriocritics simply revived Berkeley's philosophy of esse est percipi without adding any substantial arguments to this early-modern philosophy of subjective idealism. Further, he wrote that they continued old-new idealistic interpretations of Kant's a priori, which neglected the materiality of the empirical content of the categories. Writing against such traditions, Lenin praised the common sense of scientists as a form of spontaneous materialism. He even extolled a kind of "naïve realism" against those philosophers of science who considered materialism to be a form of metaphysics:

The "naïve realism" of any healthy person who has not been an inmate of a lunatic asylum or a pupil of the idealist philosophers consists in the view that things, the environment, the world, exist independently of our sensation, of our consciousness, of our self and of man in general. ${ }^{75}$

The sensations and consciousness of a person "in their right mind" are the images of the external world. Thought is a function of the brain and those who reject this idea are misled and refute basic physiology. On this point, Lenin also criticized his main intellectual adversary, Alexander Bogdanov:

\footnotetext{
73 Ibid., 76.

${ }^{74}$ Ibid., 78.

${ }^{75}$ Lenin, Collected Works, vol. 14, 69.
} 


\begin{abstract}
Bogdanov swallowed the bait of professorial philosophy in believing that "introjection" was aimed against idealism. He accepted the evaluation of introjection given by [the founder of empirio-criticism] Avenarius himself at its face value and failed to notice the barb directed against materialism. Introjection denies that thought is a function of the brain, that sensations are a function of man's central nervous system, that is, it denies the most elementary truth of physiology in order to crush materialism. ${ }^{76}$
\end{abstract}

The polemic with Bogdanov unfolded on many fronts, as the clash was political in the first place. The publication of Materialism and Empiriocriticism came in a moment of deep dissent among the two Bolshevik leaders over political strategies after the failed Russian revolution of 1905. It anticipated Bogdanov's expulsion from the party in 1909. ${ }^{77}$

As for the "external world," Lenin devoted many pages to argue for the indubitable existence of nature and of a world prior to humankind. He observed that even religions acknowledge the existence of a world prior to and independent of us, although they express this conception in mythological and not philosophical terms. According to Lenin, the Machists' bête noire is the Kantian thing-in-itself; ${ }^{78}$ they erected an insurmountable wall between the subject and the object, perception and reality, and consciousness and the world.

Against this division, Lenin defended the following three principles of gnosiology. First, things exist independently of our consciousness. Second, the distinction between phenomenon and thing-in-itself has to be rejected. The only meaningful epistemological distinction is between that which we already know and that which we do not yet know. Third, one ought to think "dialectically," that is, to consider knowledge as a process and a continuous passage from ignorance to knowledge. ${ }^{79}$ It should be remarked that all three points constitute a shift from knowledge theory to ontology or, better said, present the problems of epistemology as problems of ontology. The political meaning of this shift rests on the relevance of objectivity for practice: if we want to transform the world, we need to know it.

The problem of objectivity is also discussed in the section of Materialism and Empiriocriticism entitled "Does Objective Truth Exist?" Bogdanov is once again the target of this section, because he only admitted that objective truth existed "within the limits" of a determined epoch. As Bogdanov wrote in Empiriomonism (1904-1906), "truth is an ideological form, an organizing

\footnotetext{
$\overline{76}$ Ibid., 89-90.

${ }^{77}$ For a contextual introduction to Bogdanov's philosophy in the context of the polemics with Lenin, see the Editor's introduction to Bogdanov, The Philosophy of Living Experience (Leiden-Boston: Brill, 2016). See also Silvano Tagliagambe and Giulia Rispoli, La divergenza nella rivoluzione: filosofia, scienza e teologia in Russia (1920-1940) (Brescia: Editrice La Scuola, 2016).

${ }^{78}$ Lenin, Collected Works, vol. 14, 98.

79 Ibid., 103.
} 
form of human experience." ${ }^{80}$ Lenin objected to this by stating that, if truth depends on ideology and its socialization, there is no room for extra-human truths. He ironically argued that, since Catholic doctrines are "organized experience" par excellence, they cannot be distinguished from scientific truths by any means.

For Lenin, historical materialism does not contradict earlier forms of materialism, but only complements them. It expands the realm of application for materialism from nature to human history. Therefore, he criticized the separation of human history from the natural realm as determined by the laws of physics as a false disjunction of materialism "from below" and idealism "from above."

Marx and Engels ... entered the philosophical arena at a time when materialism reigned among the advanced intellectuals in general, and in working-class circles in particular. It is therefore quite natural that they should have devoted their attention not to a repetition of old ideas but to a serious theoretical development of materialism, its application to history, in other words, to the completion of the edifice of materialist philosophy up to its summit. ${ }^{81}$

\section{Gramsci's Path to Historical Epistemology}

Gramsci's epistemological positions oppose Lenin's on most of the points that have been considered so far. He refused to reduce epistemological problems to a dichotomy between idealism and materialism or to dismiss idealistic philosophies without understanding them and their socio-political function. For Gramsci, commonsense materialism is much closer to ordinary ways of thinking, including religion; therefore, a popular introduction to philosophy cannot begin with a discussion of theories that are too far removed from such common beliefs. Thus, according to Gramsci it is useless to begin a political discussion on the philosophy of science by rejecting Berkeley and diagnosing mental health issues for the supporters of idealistic philosophers. Such a form of criticism comes closer to religion than it would seem at first glance. According to religion, the reality of the "external" world created by God cannot be doubted, either. Hence idealism, an influential philosophy among intellectuals in spite of its counterintuitive character (as it counters both common sense and religious beliefs), is an explanandum rather than an opinion to be ridiculed:

In my view, the problem can be described thus: How can one explain that such a conception [idealism], which is certainly not futile, even for a philosopher of praxis, only provokes laughter and sneers today if it is publically introduced? It seems to me that this is the most typical case of the distance that has been formed between science and life, between certain intellectual groups, which are also in

${ }^{80}$ Quoted in ibid., 123.

${ }^{81}$ Ibid., 242. 
the "central" direction of high culture, and the great popular masses . . . But, although "common sense" is brought to laughter, the philosopher of praxis should nonetheless seek for an explanation and the real meaning of that conception [idealism], [investigate] why it was born and why it spread among intellectuals, and also why it makes common sense lough. ${ }^{82}$

For Gramsci, spontaneous materialism is in line with such immediate reactions against idealism but cannot be an argument against a culturalist comprehension of science in general. In fact, the historical materialist can learn much from the idealists, particularly the ethical-political directedness of history and the role of intellectuals as cultural agents. Croce, for one, stressed the role of intellectuals in politics. In his wake, Gramsci argued that any intellectual who is interested in politics cannot neglect ideology and the cultural direction of ideas. These two dimensions cannot be replaced with economic considerations or, even more reductively, the explanation of society through physics or biology. Gramsci also appreciated an idealistic thinker such as Croce for his criticism of economic reductionism and his discussion of the question of cultural direction, an important problem that is not exclusive to liberal or conservative politics.

Gramsci emphasized that Lenin had paid attention to this very problem. He described Lenin as the "most prominent modern philosopher of praxis" who "reassessed the front of cultural struggle in opposition to various 'economicist' tendencies and constructed the theory of hegemony as complementary to the theory of the State as force and as the actual form of the doctrine ... of the 'permanent revolution'." ${ }^{83}$ For Gramsci, the development of the revolutionary movement depended on a capacity for cultural leadership. This involved the construction of broad consensus rather than the militarization of society or the working class. He argued that the establishment of a new hegemony would also institute a new theory of knowledge, and a new human and historical consciousness. ${ }^{84}$

By contrast, a simplistic criticism of idealism runs the risk of fetishizing the natural sciences. ${ }^{85}$ When history becomes a mere repository of data for sociological analysis, sociology itself is transformed into a naïve metaphysics, just as physics itself would be according to a scientist perspective. ${ }^{86}$ But physics cannot be posited as independent from its historically determined cultural form. Such insights raise the question of whether or how the knowledge of a world

${ }^{82}$ Gramsci, Quaderni del carcere, Q. 11, \$17, 1412-1413.

${ }^{83}$ Ibid., Q. 10, \$12, 1235.

${ }^{84}$ Ibid., Q. 10, $\$ 12,1250$. Much has been written on hegemony in Gramsci. For an overview, see Angelo D’Orsi and Francesca Chiarotto, eds., Egemonie (Napoli: Dante e Descartes, 2008). In addition, see Luciano Gruppi, Il concetto di egemonia in Gramsci (Rome: Editori Riuniti, 1972) and Giuseppe Cospito, "Egemonia," in Le parole di Gramsci: Per un lessico dei Quaderni del carcere, eds., Fabio Frosini and Guido Liguori, 74-92 (Rome: Carocci, 2004).

${ }^{85}$ Gramsci, Quaderni del carcere, Q. 11, \$17, 1413.

${ }^{86}$ Ibid., Q. 11, \$ 14, 1401-1402. 
independent of humankind can be secured. Thus, how can the access to a world independent of humankind be justified? Gramsci claimed that there is no knowledge independent of ideology, which for him is the same as saying there is no objectivity independent of philosophical and historical presuppositions:

Can there be an extra-historical and extra-human objectivity? But who will judge this objectivity? Who will be able to put himself from this sort of "point of view of the cosmos in itself?" And what will this point of view mean? One may very well argue that this is a residue of the concept of God. ${ }^{87}$

According to this quotation, absolute objectivity is a religious remnant permeating the natural sciences and positivism. Religious accounts of the Creation converge with certain philosophical positions and scientific cultures. Lenin's claim that the existence of a world-in-itself is so obvious that even religions grasp it is reversed by Gramsci into a critique of the naïve philosophy of common sense.

As to Lenin's claim that historical materialism is an expansion of materialism into the cultural domain, it was inacceptable to Gramsci as he refused to view historical materialism as an appendix of the natural sciences. On this point he followed Antonio Labriola, whom he considered to be "the only one who tried to scientifically construct the philosophy of praxis by affirming that the philosophy of praxis is independent of any other philosophical tradition; it is self-sufficient." ${ }^{" 88}$ In accordance with Labriola's claims, Gramsci established a double level of "scientificity": first, that of the natural sciences; second, and prior from an ontological and gnoseological viewpoint, that of history and its fundamental conceptual tool, dialectics. The foundational character of Marxism, or the "philosophy of praxis," means that its "objectivity" cannot be deduced from that of the natural sciences. While reflecting on Marx's philosophy and viewpoints on science, Gramsci raised the following related question: "How did the concept of the regularity and necessity of historical development arise in [the work of] the founder of the philosophy of practice? A derivation from the natural sciences looks unlikely." ${ }^{89}$ Gramsci claimed that dialectics is the actual theoretical basis of "the doctrine of knowledge and the medullary substance of historiography and political science." ${ }^{\prime 0}$ His challenge was to historicize science, which in his understanding means to anchor it in the ground provided by the philosophy of praxis.

Further, the anti-metaphysical character of history is a characteristic of Gramsci's Marxism: historical materialism, despite the fact that it provides the basis for human history and

${ }^{87}$ Ibid., Q. 11, $\$ 17,1415$.

${ }^{88}$ Ibid., Q. 11, \$ 70, 1507-1578. On Gramsci and Labriola, see Francesca Chiarotto, "Antonio Labriola: Scienziato Del Materialismo Storico," in D’Orsi, Il Nostro Gramsci, 187-92.

${ }^{89}$ Gramsci, Quaderni del carcere, Q. 11, \$52, 1477.

${ }^{90}$ Ibid., Q. 11, \$22, 1425. 
knowledge, does not imply and indeed excludes the possibility of establishing a supra-historical truth, which is the dream of metaphysicians. According to Gramsci-and this is one of the most original features of his version of Marxism - a fully realized historicism recognizes the ideological character of Marxist philosophy itself: "the philosophy of praxis is itself a superstructure." 91 Thus, the central question of Marxism about the relationship of structure and superstructure reappears in a new light.

In Gramsci's reading of Marx, the superstructural side holds exceptional importance. 'Superstructures' are not "mere and fleeting 'appearances',"92 a sort of accessory epiphenomenon to the economic-political basis; instead, they are an "objective and operative reality." ${ }^{93}$ Therefore, it is necessary "to distinguish between historically organic ideologies, that is, those that are necessary to a certain structure, and arbitrary, rationalistic, 'desired' ideologies." ${ }^{\text {"9 Gramsci }}$ refers to Marx to strengthen his point: "Marx's claim is that popular persuasion often has the same energy as a material force." 95 Gramsci interprets the eleventh thesis on Feuerbach"philosophers have hitherto only interpreted the world in various ways; the point is to change it" - as an "energetic affirmation of a unity between theory and practice," 96 although he is also forced to recognize that the cultural dimension of the struggle for hegemony is only sketched out in Marx's work: "The founder of the philosophy of praxis had far broader interests than Machiavelli or even Botero and, furthermore, his work contains, in a nutshell, the ethicalpolitical dimension of politics, that is, the theory of hegemony and consensus, in addition to the analysis of force and economy." ${ }^{97}$

The concept of hegemony, which is fundamental to Gramsci's work, was borrowed and revised from Lenin's conception of the same. ${ }^{98}$ Gramsci reworks the concept in a cultural direction, enriching it with insights from Croce. On the one hand, he reassesses Georges Sorel's theory of myths as "an attempt to rephrase, in a scientific language, the conception of the ideologies of the philosophy of practice seen through . . C Croce's revisionism." ${ }^{99}$ On the other hand,

\footnotetext{
${ }^{91}$ Ibid., Q. 10, \$ 41, 1319.

92 Ibid., Q. 11, \$ 50, 1475.

93 Ibid., Q. 10, \$ 41, 1319.

${ }^{94}$ Ibid., Q. 7, \$19, 868-869.

${ }^{95}$ Ibid., Q. 7, \$21, 869.

96 Ibid., Q. 10, \$ 31, 1270.

${ }^{97}$ Ibid., Q. 10, \$ 41, 1315-1316.

98 Ibid., Q. 10, \$ 12, 1249-1250. Cf. Anna Di Biagio, "Egemonia leninista, egemonia gramsciana," in Giasi, Gramsci nel suo tempo, 379-402. On the broader debate on hegemony in Russia before and beyond Gramsci, see Craig Brandist, The Dimensions of Hegemony (Leiden: Brill, 2015).

${ }_{99}$ Gramsci, Quaderni del carcere, Q. 10, $\$ 41,1308$. The political thinker Georges Sorel (1847-1922) has been a point of reference for revolutionary syndicalism. He is particularly renowned for his Réflexions sur la violence (1906). His views on the political function of myths deeply influenced Gramsci's views on ideology.
} 
he appreciates Croce for "energetically drawing attention to the importance of cultural and intellectual facts in the development of history, to the function of great intellectuals in the organic life of civil society and the state, and to the moment of hegemony and consensus as a necessary form of a concrete historical bloc." ${ }^{100}$

The concept of "historical bloc" is as important as that of hegemony in Gramsci's thought. ${ }^{101}$ More than any other, this concept clarifies Gramsci's view of the interrelation between structure and superstructure. In fact, it forms a bridge between the economics, that is "the set of social relations in which real men move and operate," 102 and the ethical-political moment, that is to say, "the superior elaboration of the structure in the superstructure in the consciousness of men." ${ }^{103}$ Gramsci illustrates this relationship with an Aristotelian content-form metaphor: "The analysis of these statements [by Marx], I believe, leads to a strengthening of the conception of a 'historical block', in which the material forces are the content and the ideologies the form. Such a distinction of form and content is merely illustrative, because the material forces are historically inconceivable without a form and ideologies, without material forces, are individual whims." ${ }^{104}$ Thus, there is no subordination of culture to the socio-economical dimensions of human reality or vice versa; instead, there is an organic interweaving of the two, identified with the assumption of the inseparability of matter and form.

Within this framework Gramsci denies the existence of any "human nature" which has been fixed ab aeterno. ${ }^{105}$ So-called "human nature" is rather a "compound of social relations" (complesso dei rapporti sociali): "the nature of man is 'history'." 106 The study of history will therefore represent the propaedeutic for further self-understanding and for effective action projected towards the future:

\footnotetext{
${ }^{100}$ Ibid., Q. 10, $\$ 12,1235$.

${ }^{101}$ Cf. Hugues Portelli, Gramsci e il blocco storico (Rome-Bari: Laterza, 1973) and Giuseppe Prestipino, Da Gramsci a Marx: il blocco logico-storico (Rome: Editori Riuniti, 1979). Gramsci ascribes its codification to Sorel: "The concept of the concrete (historical) value of superstructures in the philosophy of praxis must be deepened by comparing it to Sorel's concept of the 'historical bloc'." Gramsci, Quaderni del carcere, Q. 10, 1321.

102 Ibid., Q. 10, \$8, 1226.

103 Ibid., Q. 10, \$ 6, 1244.

${ }^{104}$ Ibid., Q. 7, \$21, 869.

105 Cf. Alberto Postigliola, Su natura umana e storia in Gramsci (nota sul S 12 del Quaderno 16), in Politica e storia in Gramsci, ed. Franco Ferri, 578-586 (Rome: Editori Riuniti, 1977).

106 Gramsci, Quaderni del carcere, Q. 7, 885. Cf. Cesare Luporini, "La metodologia del marxismo nel pensiero di Gramsci," in Studi gramsciani, eds. Roberto Cessi, Eugenio Garin, Cesare Luporini and Palmiro Togliatti, 445-468 (Rome: Editori Riuniti, 1969), 457.
} 


\begin{abstract}
The beginning of critical reflection [elaborazione critica] is the awareness of who one really is, that is, 'knowing oneself' [conosci te stesso] as a product of the historical process that has hitherto taken place and has left an infinity of traces in oneself, which are accepted without some reservations [senza beneficio d'inventario]. ${ }^{107}$
\end{abstract}

Once the concrete historical ground in which people operate has been clarified, there will finally be the space for what Gramsci calls a "catharsis," by which he means an emancipatory leap forward:

the passage "from the objective to the subjective" and from "necessity to freedom." The structure is transformed from an external force that crushes men, assimilates them to itself, and makes them passive into a means of freedom, an instrument to create a new ethical-political form, and the source of new undertakings. ${ }^{108}$

In revolutionary yearning, the historicism of Gramsci acquires its most proper articulation and illuminates the meaning of the philosophy of praxis as "past and current history" (storia fatta $o$ in fieri).

\title{
Science, Society, and Historical Materialism: For Lenin against Lenin
}

In spite of their ostensible divergence as far as the philosophy of science is concerned, Gramsci credits Lenin as the reference point for his conceptions of praxis and hegemony, and even goes so far as to include Lenin's ideas on the implementation of a cultural line in politics in his own reflections. The clarification of the philosophical premises of such a conception led him to use Lenin, quo the philosopher of praxis, against Lenin, quo the philosopher of science. Three important points of convergence between the two thinkers can be found in their views on science, society and historicity, which Lenin particularly discussed in the second part of his Materialism and empiriocriticism: 1. the rejection of scientism as a supporting arch of Marxism; 2. the concept of a leap from natural necessity to praxeological freedom; and 3. the importance of objectivity as a means of transforming reality.

1. Against scientism: As for the first issue, Gramsci shares Lenin's rejection of the idea that Marxism needs the natural sciences as a ground on which to construct historical materialism. It is in chapter six of Materialism and Empiriocriticism, entitled "Empirio-Criticism and Historical Materialism," that Lenin especially develops his criticism of the attempts to give natural, biological, and sociological foundations to historical materialism. In this chapter he expands on the social sciences in a discussion that constitutes a critique directed towards German empiriocriticism, but especially against Bogdanov's Empiriomonism.

\footnotetext{
107 Gramsci, Quaderni del carcere, Q. 11, \$12, 1376.

${ }^{108}$ Ibid., Q. 10, \$ 6, 1244.
} 
Lenin considers the manner in which German Machist epistemologists entered socio-economic studies. Many of them rejected Marxism. For instance, Richard Avenarius and his pupils criticized Marx's conception of economy, arguing that it constituted a pseudo-metaphysical principle upon which the comprehension of society is erected without any preliminary gnosiological reflection. This criticism bears a close similarity to Croce's criticism of economicism as the hidden theology of Marxism, with which Gramsci thoroughly engaged as a way to develop his own escape from economic reductionism without renouncing socio-economic analysis.

Moreover, Avenarius criticized Marx's separation of economy from biology and therefore can be said to have favored an evolutionist conception of history derived from biology. Additionally, he accused Marx and his followers of being partisan and thus abandoning the terrain of scientific impartiality for one-sided factionalism. As for Bogdanov, Lenin was very critical of his attempt to reconcile Machism and Marxism by rephrasing the latter's understanding of society in energetic and biological terms. He argues that, in spite of his "good intentions," Bogdanov confuses the theory by replacing dialectics, the specific method of the Marxist analysis of society, with scientism, that is, a methodology derived from biology and positivist sociology. "It needs hardly be said that all this play with biology and sociology contains not a grain of Marxism." 109 The risk of social Darwinism is clearly perceived and argued against through the words of Karl Marx himself. Lenin quotes a letter from 1870 directed against Lange's reduction of societal developments to the struggle for life:

Herr Lange, you see, has made a great discovery. The whole of history can be brought under a single great natural law. This natural law is the phrase (in this application Darwin's expression becomes nothing but a phrase) "struggle for life," and the content of this phrase is the Malthusian law of population or, rather, over-population. So, instead of analyzing the "struggle for life" as represented historically in various definite forms of society, all that has to be done is to translate every concrete struggle into the phrase "struggle for life," and this phrase itself into the Malthusian "population fantasy." One must admit that this is a very impressive method-for swaggering, sham-scientific, bombastic ignorance and intellectual laziness. ${ }^{110}$

109 Lenin, Collected Works, vol. 14, 327.

${ }^{110}$ Karl Marx to Kugelmann, June 27, 1870, quoted in Lenin, Collected Works, vol. 14, 308. 
Gramsci shares this aversion to socialist attempts to contrive evolutionary models of social progress, for instance those arising from Italian popularizers of positivism like Achille Loria. He regarded their religion of progress as obscurantist and as misleading as other forms of religious ideology. ${ }^{111}$

2. A leap forward from natural necessity to praxeological freedom: A second important point of convergence between Lenin and Gramsci's (historico-political) epistemologies concerns the leap from natural necessity to praxeological freedom through revolutionary praxis. The relevant section in Materialism and Empiriocriticism is to be found in a section of chapter three entitled "Freedom and Necessity." Natural necessity and free action are not mutually exclusive; the latter is grounded in the former. As Lenin argues by quoting Friedrich Engels,

freedom does not consist in an imaginary independence from natural laws, but in the knowledge of these laws, and in the possibility this gives of systematically making them work towards definite ends. ... Freedom therefore consists in the control over ourselves and over external nature, a control founded on knowledge of natural necessity (Naturnotwendigkeiten). ${ }^{112}$

Indeed, according to Lenin, it is because of the imperative to transform reality that the importance of objective knowledge cannot be renounced. This is perhaps the most important insight to be gleaned from his work on epistemology. In the title of a section of chapter two, Lenin defines it as "The Criterion of Practice in the Theory of Knowledge." Its political relevance becomes clear in the discussion of the social sciences and historical materialism. In order to change society, one needs to "know." Objectivity is the aim of both science and of transformative praxis.

But objectivity should not be confused with impartiality. Economy is the paradigmatic field for revealing scholars' partisan biases and the manner in which their agendas influence their theories and explanations. In a section of chapter six, "Parties in Philosophy and Philosophical Blockheads," Lenin argues that,

\footnotetext{
${ }^{111}$ Gramsci, Quaderni del carcere, Q. 28. For a reappraisal of Gramsci's criticism of Loria in the perspective for a renewed criticism of positivism in current biological debates, see Roger Cooter, "Gramsci in PostPostmodernity: Capitalism, Science, and 'Human Nature,", in Cultural Hegemony in a Scientific World: Gramscian Concepts for the History of Science, eds. Massimiliano Badino and Pietro Daniel Omodeo (Leiden: Brill, 2020), chap. 14.

${ }^{112}$ Lenin, Collected Works, vol. 14, 187.
} 


\begin{abstract}
not a single professor of political economy, who may be capable of very valuable contributions in the field of factual and specialized investigations, can be trusted one iota when it comes to the general theory of political economy. For in modern society the latter is as much a partisan science as is epistemology. Taken as a whole, the professors of economics are nothing but learned salesmen of the capitalist class, while the professors of philosophy are learned salesmen of the theologians. ${ }^{113}$
\end{abstract}

Philosophy, particularly the philosophy of science, is a political matter. This idea is encapsulated in the conclusive statement: "Recent philosophy is as partisan as was philosophy two thousand years ago." 114

3. The political struggle for objectivity: While Gramsci's rejection of scientism, his defense of Marxism's autonomy from positivism, and the dialectics of necessity and freedom are wellknown aspects of his thought, his position on objectivity and the transformation of the world has been less discussed. According to Lenin, objectivity and materialism belong together, whereas Gramsci, as I have shown, dismisses biases towards common-sense materialism as a metaphysical error. Hence, contrary to Lenin, he does not appeal to scientists' common sense, but rather views this form of knowledge as ideological as well.

Gramsci focused on the practical dimension of science instead of the "intuition" of scientists. He emphasized the importance of the interaction with reality, which forms the basis for scientists' experimental activity, and also noted that this is only an elementary form of the interactions between culture and nature.

Scientific experience is the first cell [cellula, kernel] of the new method of production, of the new form of active union between man and nature. The scientist-experimenter is also a worker, not a pure thinker, and his thinking is continuously controlled by practice and vice versa, until the perfect unity of theory and practice is formed. ${ }^{115}$

In this sense, scientific activity is exemplary of the connection between theory and praxis as theorized by Marxism. Drawing on these premises, Gramsci was led to acknowledge the socioeconomic context of experimental activity. The "practical" dimension of such activity cannot be reduced to the "instrument" or the "material' but has to be conceived in broad culturalpolitical terms:

\footnotetext{
${ }^{113}$ Ibid., 342-343. Italics in the original.

114 Ibid., 358.

115 Gramsci, Quaderni del carcere, Q. 11, \$ 34, 1449.
} 
The philosophy of praxis does not study a machine in order to know and establish the atomic structure of the material ..., but in order to assess it as an object owned by certain social forces, as the expression of a social rapport which corresponds to a specific historical period. ${ }^{116}$

Gramsci also considered the pedagogical value of science to be an educational tool for overcoming

folklore with all its traditional residues of world conceptions [in order] to spread a more modern conception, whose primitive and fundamental elements are given in the learning of the existence of the laws of nature as something objective and rebellious, which one must adapt to in order to hold dominion over. ${ }^{117}$

Historical materialism is presented as the only cultural movement capable of

reconciling popular culture and experimental science with a vision of the world that is neither gross positivism, convoluted actualism [Gentile's philosophy], nor bookish neo-Thomism [Catholic philosophy]. ${ }^{118}$

Thus, Gramsci resolved the problem of the value and status of science by establishing its historical foundation within the framework of the "philosophy of praxis."

Therefore, far from embracing an abstract idealism (or a spiritualistic philosophy), Gramsci instead proposes a praxeological vision of science which does not deny either reality or objectivity, but only refuses their transcendental comprehension as something that can be accessed at the level of an extra-human and extra-historical reality. The objectivity of the sciences rests in its capacity to transform the world. Objectivity rests on the connection of theory and praxis and science makes such a connection possible in the first place. Although science is ideological, it occupies a special position among the "superstructures" since it establishes the closest possible connection between thought and action and between culture and economy:

Actually, even science is a superstructure, an ideology. One can say, however, that in the study of superstructures, science occupies a special place, for its relation to the structure has a particular character, wider in extension and closer [to the basis] as far as the continuity of its development is concerned. ${ }^{119}$

Science is an ideology, but this does not imply any abstract arbitrariness. Ideology is always rooted in concrete reality, that is, history, and has real power. "Ideologies are everything but arbitrary; they are real historical facts." ${ }^{120}$ Marxism itself is an ideology, which is to say that it

\footnotetext{
116 Ibid., Q. 11, $\$ 30,1443$.

117 Ibid., Q. 12, \$ 2, 1540.

118 Ibid., Q. 10, $\$ 11,1249$.

119 Ibid., Q. 11, \$38, 1457.

${ }^{120}$ Ibid., Q. 10, $\$ 41,1319$.
} 
influences the objective transformation of reality but is still engrained within the very reality it emerges from.

A fundamental point of reference for these considerations on ideology and the transformation of reality are Marx's theses on Feuerbach, which Gramsci translated and meditated upon in prison. The first two theses are crucial for the epistemological considerations which are of concern here (not only for Gramsci but for Lenin, too):

1. idealism ... does not know real, sensuous activity as such. Feuerbach wants sensuous objects, really distinct from conceptual objects, but he does not conceive human activity itself as objective activity. . Hence he does not grasp the significance of "revolutionary," of "practical-critical" activity.

2. The question of whether objective truth can be attributed to human thinking is not a question of theory but a practical question. Man must prove the truth, i.e., the reality and power, the this-sidedness of his thinking in practice. The dispute over the reality or non-reality of thinking which is isolated from practice is a purely scholastic question. ${ }^{121}$

The objectivity of ideology, in particular of science as material ideology in its ability to transform reality, can be judged in the example of Fordism, the new methods of production developed in America and rapidly imported to Europe which, in various forms, presupposes the creation of a new kind of worker who is "educated" to labor mechanically "like a gorilla" (in Frederick Taylor's famous metaphor) in the assembly line, and whose behavior (including sexuality) is repressed and controlled. Puritanism and alcohol prohibition are the cultural expressions of the transformation induced by the Fordist "rationalization" of production:

In America, the rationalization of labor and prohibitionism are undoubtedly connected: the requests of the industrialists concerning the intimate life of the workers, the inspection services created by some companies to control the "morality" of the workers, are a necessity for the new way of working. Those who mocked these initiatives (even if they did not succeed) and saw in them only a hypocritical manifestation of "puritanism," are not in the position of understanding the importance, the meaning and the objective import of the

${ }^{121}$ Karl Marx, Theses on Feuerbach [1845] in Marx and Friedrich Engels, Collected Works, vol. 5 (New York: International Publishers, 1975), 3. Italics in the original. Cf. Gramsci's translation Notebook 7:

1. [...]l'idealismo [...] ignoral'attività reale, sensibile, come tale. Feuerbach vuole oggetti sensibili realmente distinti dagli oggetti del pensiero; ma egli non concepisce la attività umana stessa come attività oggettiva. [...] Pertanto egli non concepisce l'importanza della attività 'rivoluzionaria', dell'attività pratico-critica.

2. La quistione se al pensiero umano appartenga una verità obiettiva, non è quistione teorica, ma pratica. È nella attività pratica che l'uomo deve dimostrare la verità, cioè la realtà e il potere, il carattere terreno del suo pensiero. La discussione sulla realtà o non-realtà di un pensiero, che si isoli dalla praxis, è una quistione puramente scolastica. Antonio Gramsci, Quaderni di traduzioni (1929-1932), 1. 1., eds. Giuseppe Cospito and Gianni Francioni (Rome: Istituto della Enciclopedia Italiana, 2007), 743. 


\begin{abstract}
American phenomenon. This is also the greatest collective effort that we have seen so far aimed at creating a new type of worker and person with unprecedented speed and with an awareness of the goals never seen in history. ${ }^{122}$
\end{abstract}

In pages like this, which are taken from the notes on "Americanism and Fordism" in Notebook 22, Gramsci pointed out the objectivity of the connection between technology, science, and production, and worldviews, ethics, and consciousness. Science is at the center of this juncture, not only because it is connected with technology and production, but also because it provides the technical basis for the rationalization of work.

"Americanism" is a good instance of such a scientific reorganization of life constitutes "a real action, which modifies both man and the external reality (that is, the real culture) in their essence." ${ }^{123}$ In this perspective, the struggle for hegemony is directed towards the most objective and universal comprehension of social and natural reality in order to transform both. Science plays a decisive role in a process that can become emancipatory only if it is universalized, that is, if it fosters the largest interests of humankind and not those of particular groups:

There is . . . a struggle for objectivity (to get rid of partial and fallacious ideologies) and this struggle is the same struggle for the cultural unification of the human race. . . Experimental science has so far been . . . the terrain in which such a cultural unity has reached its maximum extension: it has been an element of knowledge that has contributed to unifying the "spirit", to making it become more universal; it is the subjectivity that has been concretely objectivized and universalized to the highest degree. ${ }^{124}$

Objectivity means the transformation of reality. It is not extra-subjective contemplative correspondence between theory and facts but the subjective reshaping of the world. ${ }^{125}$

\title{
Concluding Remarks
}

In spite of being imprisoned, Gramsci's reflections on science, scientific culture and epistemology ought to be seen as reflections from one of the key voices in the leftist debates on the history and philosophy of science that reached their culmination in the 1930s. Gramsci directly responded to stimuli that came to him from the texts he could access, such as Science at the Cross Roads, which included Bukharin's London speech on science and Marxism, or Mirskij's essay,

\footnotetext{
${ }^{122}$ Gramsci, Quaderni del carcere, Q. 22, \$11, 2164-2165.

123 Ibid., Q. 22, \$5, 2152.

${ }^{124}$ Ibid., Q. 11, $\$ 17,1416$.

${ }^{125}$ On the interdependency of the concept of hegemony and international economic relations pointing to a unification of the globe, cf. Giuseppe Vacca, "Dall" egemonia del proletariato' alla 'egemonia civile": Il concetto di egemonia negli scritti di Gramsci fra il 1926 e il 1935," in D’Orsi and Chiarotto, Egemonie, 77-122, esp. 106-10.
} 
published in the Labour Monthly, on the philosophical discussions in the Communist Party of the Soviet Union in 1930-1931, which saw the clash between the supporters of dialectics against those searching for a Marxist foundation in the natural sciences.

The legacy of Lenin's Materialism and Empiriocriticism (1909) is in the background of these controversies, as it provides a strenuous defense of materialism, the objectivity of science, and Marxism's autonomy from positivism. Therefore, it is important to not only see Gramsci's writing as a critical reaction to Bukharin's position, but also as a document that includes his two-sided reception of Lenin's political epistemology. On the one hand, he agreed that praxis and politics must be central to a correct assessment of the meaning, value, and legitimacy of epistemological positions; on the other hand, he disagreed with the reduction of the problem of epistemology to the dichotomy of materialism and idealism at the expense of any considerations on the ideological dimension of science as a cultural phenomenon. Against the assumption of the accessibility of a reality independent from subjectivity, Gramsci emphasized, more in line with the Machists than with their critics, the political relevance of the struggle for objectivity, but also, more in line with Lenin than with the Machists, he denounced the ideological dimension of scientism and the urgency of a reflection on the cultural politics of science as a form of collective action. His aim was to open up a novel path to the comprehension of science in the framework of a philosophy of praxis capable of bringing together dialectical materialism and historicism.

In many ways, Gramsci fought for the relative autonomy of Italian and international struggles and theoretical conceptions, a point which should not be reduced to a position solely within the clashes taking place in the Soviet Union. Gramsci was against Stalin's politics of Socialism in a single country and his request for all Communist parties to support his position in Soviet Union. He refused to accept the subordination of the international Communist movement to the agenda of one country, which in his view neglected essential local particularities and hampered the revolutionary project overall. Already in 1926, in a famous letter he sent, on behalf of the Political Office of the Italian Communist Party, to the Central Committee of the Russian Communist Party (October 14), he objected to Stalin's request that all of the Communist parties should endorse the condemnation of Trotsky and his hardline position as a nationalist stance that threatened world revolution. In Gramsci's opinion, the clashes for power and the disunity that followed Lenin's death in the Soviet Union should not be exported to other countries. This also implied the rejection of an international Marxist orthodoxy that would be established in Soviet Union. ${ }^{126}$ Gramsci's critical reception of Lenin, freely developed from the latter's polemics with the Machists (in particular, Bogdanov), attests to his effort to create an autonomous path for Marxism, one which was in dialogue with the Soviets but not

${ }^{126}$ Vacca, Vita e pensieri di Antonio Gramsci. 
dependent on any dogmatization. ${ }^{127}$ As Gramsci noted in Notebook 11, in a section on the "Concept of 'orthodoxy" (Concetto di "ortodossia"):

\begin{abstract}
Orthodoxy must not be sought in this or that of the followers of the philosophy of praxis, in this or that tendency linked to currents that are extraneous to the original doctrine, but in the fundamental concept that the philosophy of praxis "suffices for itself," as it contains in itself all the elements that are fundamental not only to construct a total and integral conception of the world-a total philosophy and theory of the natural sciences-but also to enliven an integral practical organization of society, that is, to become a total, integrated civilization. ${ }^{128}$
\end{abstract}

While praxis is central to the political epistemologies of both Lenin and Gramsci, they elaborated upon it in different ways. Both ascribed great importance to objectivity as necessary for transformative action. However, while this practical-theoretical necessity led Lenin to stress the materiality of scientific knowledge and neglect history, Gramsci stressed the objectivity of the historical path itself and renounced the hypostatization of the referent of knowledge as metaphysically misled. Both criticized positivism: Lenin as a philosophy that cannot offer the ontological foundations to dialectical and historical materialism; Gramsci in terms of its scientist bias that hypostatizes a certain moment in the cultural development of science. In anachronistic terms, we can say that Lenin dismissed constructionism as a form of idealism, maintaining his focus on the referent's materiality. ${ }^{129}$ By contrast, Gramsci embraced a constructionist vision of science, as an ideological form mirroring a certain stage of the development of historical subjectivity. For Gramsci, however, culture was not a mere epiphenomenon, but rather an integral part of historical reality. He saw it as an objectivizing force. Ideology transforms the world because it is part of the world, and science is the highest form of this transformative power of culture. Hence, while science can be criticized for its function as an instrument of legitimacy, as is the case with scientism (even in the Marxist camp), it also acts as a means of world transformation. Thus, science is the "kernel" of the praxis-oriented philosophy propounded by Marx in his theses on Feuerbach. In his effort to avoid the Scylla of a positivistic veneration of a naturalized science on the one hand, and the Charybdis of idealistic and historicist anti-scientific attitudes on the other, Gramsci welcomed the praxeological tendency of Marxist-Leninist epistemology. Thus, Gramsci and Bukharin can

\footnotetext{
${ }^{127}$ It has even been surmised that Gramsci's emphasis on the cultural dimension of politics and the conception of scientific objectivity as the result of social activity might point to a connection between him and Bogdanov. See Zenovia A. Sochor, "Was Bogdanov Russia’s Answer to Gramsci?" Studies in Soviet Thought 22, no. 1 (1981): 59-81.

${ }^{128}$ Gramsci, Quaderni del carcere, Q. 11, \$27, 1434.

${ }^{129}$ It might be interesting to note at this point that, in reaction to Lenin, Bogdanov defended a vision of "reality as social practice" in a section dedicated to "Objectivity" in The Philosophy of Living Experience, written between 1910 and 1911. Like Gramsci, Bogdanov drew on Marx's theses on Feuerbach in order to co-opt Marx and "understand reality, Wirklichkeit—-the objective world-as human practice and therefore as social." Bogdanov, The Philosophy of Living Experience, 215.
} 
be seen as the embodiment of two different lines of reception of Lenin, historical praxeology versus scientist materialism, respectively.

Gramsci developed Marxism in the direction of a philosophy (of praxis) in which culture acts as a material force of transformation. To this end, he translated Croce's philosophy of history in Marxist terms and, vice versa, revised Lenin's epistemology in historicist terms. One can frame the benefits and limits of this contribution thus: a socio-political historical epistemology that rejects any attempts to absolutize the facts and theories of the natural sciences and, even worse, the naturalization of history. For Lenin, objectivity was the necessary presupposition for transformation, because the imperative to know reality as it is provides the condition for real change. Gramsci agreed with this but emphasized another part of the idea: since objectivity coincides with historical subjectivity, its highest degree can only be reached through the unification of humanity. The political goal of an emancipated world can only be envisaged through a "struggle for the cultural unification of the human race." 130 This (ultimately epistemological) struggle, as the struggle for objectivity, coincides with the effort for the creation of a new world.

${ }^{130}$ Gramsci, Quaderni del carcere, Q. 11, $17,1416$. 


\section{Acknowledgements}

The completion of this essay, during the COVID-19 quarantine of March 2020, has been made possible thanks to the availability of digital resources of the Max Planck Institute for the History of Science, Berlin, and its library, to which I am particularly thankful.

I would like to express my gratitude to Lukas Meisner for our ongoing conversations and collaboration on the "dialectics of positivism and postmodern" in current debates on science. For comments and support, I would like to especially acknowledge Sascha Freyberg, Rodolfo Garau, Giulia Rispoli, and the blind referees. I would like to thank Lindsay Parkhowell for the stylistic revision of this essay and his comments.

\section{Competing interests}

The author has declared that no competing interests exist.

\section{Funding}

This essay is a contribution to the theoretical and methodological foundations of the project Institutions and Metaphysics of Cosmology in the Epistemic Networks of Seventeenth-Century Europe, which is funded by the European Research Council with a consolidator grant (Early Modern Cosmology, Horizon 2020, GA: 725883). 